\title{
The Stochastic Determinism of Aging and Death
}

\author{
MOMČILOVIĆ BERISLAV ${ }^{1}$ \\ PREJAC JURAJ ${ }^{2}$ \\ VIŠNJEVIĆ VJERAN ${ }^{1}$ \\ MIMICA NINOSLAV ${ }^{3}$ \\ ${ }^{1}$ Institute for Research and Development \\ of Sustainable Ecosystems, Srebrnjak 59, \\ 10000 Zagreb, Croatia \\ ${ }^{2}$ University Hospital Centre Zagreb, Department \\ of Oncology, Kišpatićeva 12, Zagreb, Croatia \\ University of Zagreb, School of Dental Medicine, \\ Gundulićeva 5, 10000 Zagreb, Croatia \\ ${ }^{3}$ University Psychiatric Hospital Vrapče, \\ Bolnička cesta 32, 10090 Zagreb, Croatia \\ School of Medicine, University of Zagreb, Šalata 3, \\ 10000 Zagreb, Croatia

\section{Correspondence: \\ Berislav Momčilović \\ e-mail: berislav.momcilovic@gmail.com}

Key words: aging, life expectancy, death, determinism, randomness, sex

Received February 19, 2015

Revised February 02, 2018.

Accepted May 19, 2018.

\section{Abstract}

Background. We have studied human life expectancy in Croatia.

Materials and Methods. Local daily papers reported obituitairies for 447 men and 366 women who died in a month period. The data were analyzed with the median derivative power function model.

Results. The median age of death was 76 and 81 years for men and women, respectively. Cummulative mortality increases at a constant rate after the age $60 y$ and $65 y$ for men and women, respectively $\left(r^{2}=0.99\right.$ and 0.98).

Conclusions. Individual life span is a stochastic (random) biological event within the deterministic frame of cumulative mortality.

\section{INTRODUCTION}

W may define the crucial steps in a common life cycle, i.e., conception, birth, growth \& development, maturity, senescence, and death. Evidently, the life cycle is a time limited affair unless one believes in resurrection (Christianity), reincarnation (Buddhism), and transformation (Taoism) of his/her eternal soul. As the world population is living longer, the number of older people is also growing and centenarians are not exceptionally rare today (2). Presently, geriatry is a recognized medical discipline on its own as it became evident that the health and disease of senescent (aged) population forms a distinct medical entity (3).

Senescence is characterized by the involution of all the body organs, the shrinking of their size and decrease of their functional capacity (4). Indeed, the brain is shrinking (5), hormone production is being reduced (6), hair follicles are decaying (7), muscle are losing mass $(8,9)$, skin is losing its quality (10), bones are becoming brittle (11), genetic expression is slowing down (12) ... - it is like Kubrick's HAL 9000 (Heuristically Programmed Algorithmic Computer) from „2001 A Space Odyssey," a movie where the entire space ship, and not only its artificial intelligence, is decaying, and where the rate of decaying of different components of the system may not be uniform. Today, special attention is payed to the mobility of senescent patients, their gait and vigour of movements, and cognitive capacity - all in order to help sustain their self-reliance. Indeed, the involution of the muscle-skeletal system in the senescent persons due to muscle mass loss (sarcopenia) $(8,9)$ and bone loss (osteoporosis)(11) make senescent people more prone to falling and bone fractures. Apparently, regular physical activity is essential for health of senescent people, at the least as long as such a capacity for mobility is sustained (13). Adequate diet also should be included (14, 


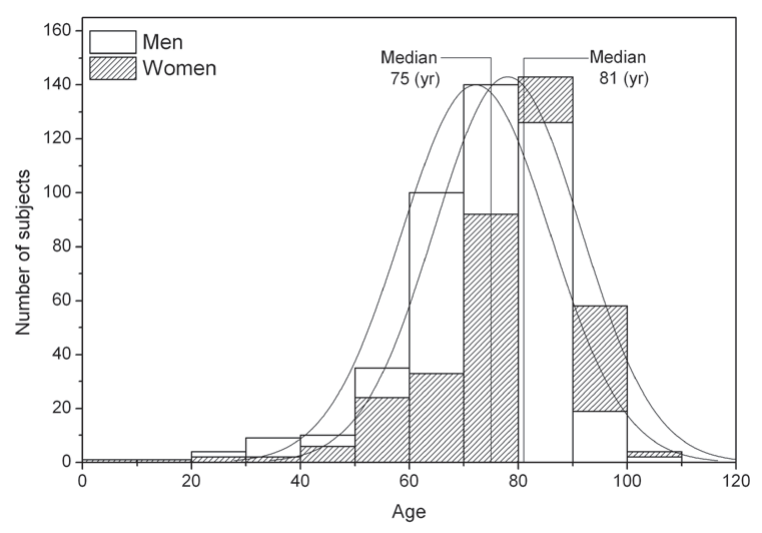

Figure 1. Medians and mortality frequency distribution for men and women

15). At present, there is no available scoring system of validation which can reliably assess and grade the physical status of the aging people and their fraility (16).

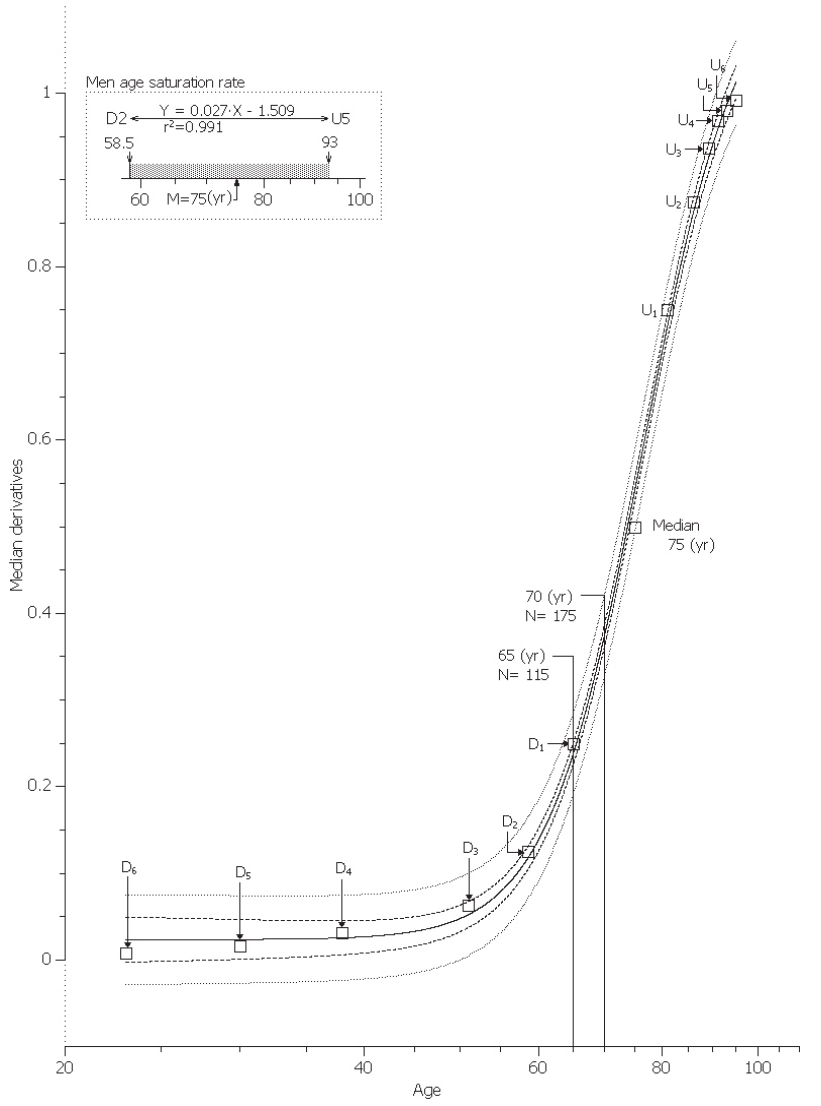

The first author's personal encounter with senescence came when he was refused a travellers health insurance because he was over 71 years old. Since everybody's biological and chronological age may differ, that refusal stimulated him to look at human life expectancy, and to uncover how reliable insurance company profit rules may be. In other words, why do the insurance companies think that they would loose more money then they would make, if they insure one person at the age of 71 . Indeed, and for the record, the first author encounter with senescence was when his Institute retired him at the age of $65 \mathrm{y}$. This study clearly demonstrated that such life span time boundaries are a sancta simplicita bureaucratic delusion of not differentiating between the biological and chronological age, respectively.

\section{SUBJECTS AND METHODS}

During the summer months August 15 till September 15,2013 , the first author of this paper followed the obituaries published in a daily newspaper Večernji List (edition

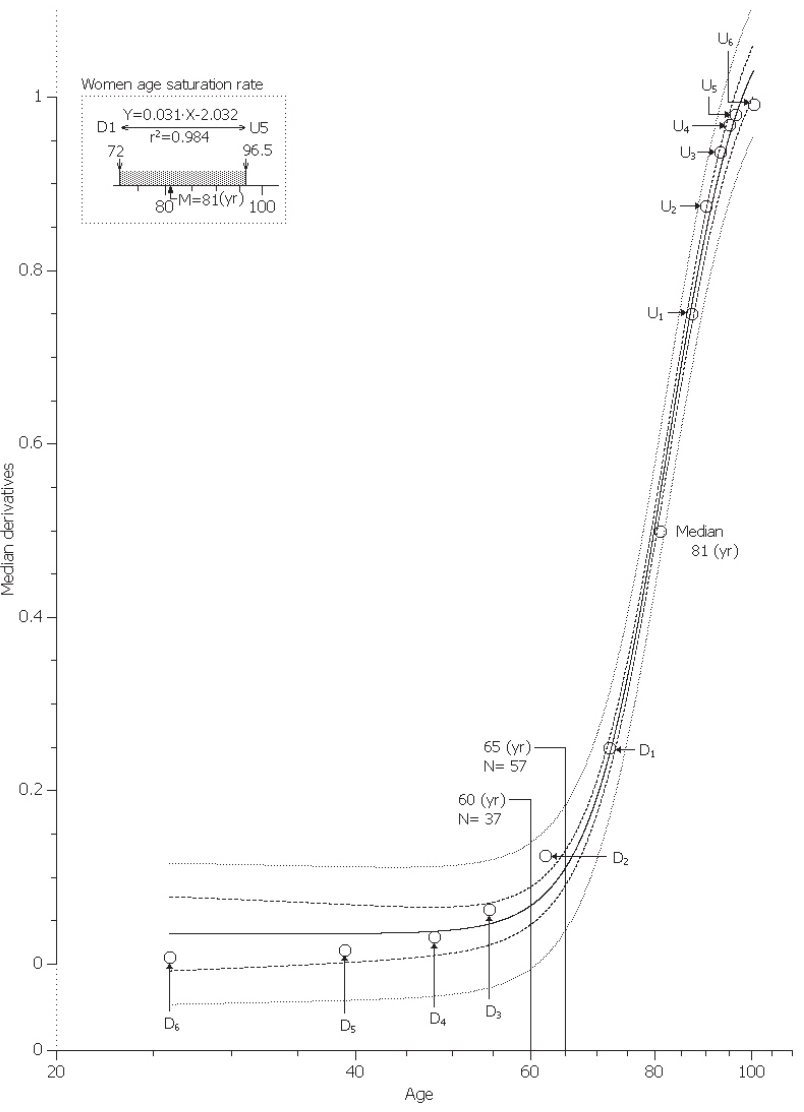

Figure 2. The power function of the mortality median derivative frequency distribution: Men=477 ( $\square$ ) and Women=366 (O). D, U Men downward $(D)$ and upward $(U)$ median derivatives, $d, u$ Women downward (d) and upward $(u)$ median derivatives.

--- Logistic function: $A_{2}+\left(A_{1}-A_{2}\right) /\left(1+(X / X)^{p}\right)$,

--0.95 confidence limit, $\cdots 0.95$ prediction limit

Men: $\left.\quad Y=1.15+(-0.02-1.15) /[1+X / 76.43)^{9.00}\right]$

Women: $\left.\quad Y=1.14+(-0.03-1.14) /[1+X / 82.14)^{11.13}\right]$

(see Appendix for model and Table 1. for input values) 
for Primorsko-goranska županija, CROATIA). There were 813 obituaries reported ( 447 men and 366 women), showing their birth and death dates or total life span in years; there were also 54 more subjects of both sexes whose obituaries did not provide enough data to calculate their length of life. Since the data were publically displayed, and since their names or other whereabouts were not used, there were no ethical considerations involved in this study that would require an informed consent or implementation of the Declaration of Helsinki (17).

Traditionally, the mortality rates are calculated by Gompertz attrition model of actuarial statistics and its numerous variants (18). This method oversimplifies and ignores the non-linear aspects of mortality frequency distribution curve (mortality tables); regardless of its limitations the method is the founding stone of the insurance business in the world today. To scrutinize mortality frequency distribution, we used the median derivative model (Appendix 1) to fit the sigmoid logistic regression analysis function for life span and mortality frequency of men and women separately

$$
\mathrm{A}_{2}+\left(\mathrm{A}_{1}-\mathrm{A}_{2}\right) /\left[1+\left(\mathrm{x} / \mathrm{x}_{0}\right)^{\mathrm{P}}\right]
$$

where $A_{1}$ is initial value (lower horizontal asymptote), $A_{2}$ is final value (upper horizontal asymptote), $\mathrm{x}_{0}$ is centre (point of inflection, in our case it is the median $\mathrm{M}_{0}$ ), $\mathrm{p}$ is power (the parameter that affects the slope of the area about the inflection point). The Qtiplot Data Analysis and Scientific Visualisation program was used for this analysis (www.soft.proindependent.com/qtiplot.html). We used this model for assessing the respective environmental silver body exposure and iodine nutritional status $(19,20)$.

\section{RESULTS AND DISCUSSION}

The median life expectancy of men was approximately six years lower than that of women; it was approximately 75 years for men and 81 years for women (Fig.1). When the data on the age of death (Table 1) were presented as a median derivative power function (Appendix 1), a sigmoid saturation curve was generated having a long linear segment of cumulative mortality. The sigmoid curves with their linear segments are presented separately for men (Fig. 2a) and women (Fig. 2b). Evidently, the scythe of death was reaping human lives at a steady exponential rate, indicating that presently half of all the living men and women won't make their $75^{\prime}$ or 81 ' birthday, respectively. The chance of a man of my generation 42 ' to became a centenarian, is less than one percent.

That the number of living persons is decreasing with the increased age is not a surprise. However, it is disturbing, that already at the age of 50 the life expectancy started to diminish at an accelerated rate. Indeed, half of men and women would not make it to live up till the age of $75 \mathrm{y}$ for men and age $81 \mathrm{y}$ for women. That fact of life, e.g. that there is a human population having a short life span, is usually neglected. Apparently, some humans may have a decisive determinant that their candle of life, or vital breath, or whatever, is going to run out short, and leave them in oblivion at an early age. This process of dying is certainly deterministic, because we will all die some time, but it is also stochastic (random) because we still do not know who will be the one called out from the stream (flow) of life (21). Our results point to the sobering fact that the average life expectancy is our statistical mental construct suitable for actuarial statistics of the insurance companies (18). However, this analysis also shows how senescence and mortality, although related phenomena, are distinct entities. After the age of $60 \mathrm{y}$ for men, and $65 \mathrm{y}$ for women, the human population, i.e., the human population biomass („,bioplasma"), is decaying (dying) at an impressive constant rate $\left(r^{2}=0.99\right.$ and 0.98 for men and women, respectively). The fact that we all belong to some geneticaly defined group of life forms, e.g., humans in this particular case, and hence we all have some common features discernible by statistical analysis (mortality), it is still far away from determining what actually induces individual rates of aging and death, i.e., your or my life span.

The key element of senescence appears to be the loss of our viable cells across the tissues and organs of the body, so that the cellular matrix, like a coral reef, remains after

Table 1. Mortality median derivative frequency distribution (MDFD): Men $\left(D_{1}-D_{6}\right.$ downward $M D F D, U_{1}-U_{6}$ upward MDFD) and Women $\left(d_{1}-d_{6}\right.$ downward MDFD, $u_{1}-u_{6}$ upward MDFD).

\begin{tabular}{|cccccccccccccc|}
\hline \multicolumn{4}{c}{} & $\mathrm{MEN}$ & \multicolumn{3}{c}{ Median $\left(\mathrm{M}_{0}\right)_{\mathrm{n} 477}=75 \mathrm{yr}$} & \multicolumn{5}{c}{ WOMEN } & \multicolumn{3}{c|}{ Median $\left(\mathrm{M}_{0}\right)_{\mathrm{n} 366}=81 \mathrm{yr}$} \\
\hline $\mathrm{MDC}$ & $\mathrm{n}$ & Age & MDC & $\mathrm{n}$ & Age & MDC & $\mathrm{n}$ & Age & MDC & $\mathrm{n}$ & Age \\
\hline $\mathrm{D}_{1}$ & 224 & 65 & $\mathrm{U}_{1}$ & 224 & 81 & $\mathrm{~d}_{1}$ & 183 & 72 & $\mathrm{u}_{1}$ & 183 & 87 \\
$\mathrm{D}_{2}$ & 112 & 59 & $\mathrm{U}_{2}$ & 112 & 86 & $\mathrm{~d}_{2}$ & 92 & 62 & $\mathrm{u}_{2}$ & 92 & 90 \\
$\mathrm{D}_{3}$ & 56 & 51 & $\mathrm{U}_{3}$ & 56 & 89 & $\mathrm{~d}_{3}$ & 46 & 55 & $\mathrm{u}_{3}$ & 46 & 93 \\
$\mathrm{D}_{4}$ & 28 & 38 & $\mathrm{U}_{4}$ & 28 & 91 & $\mathrm{~d}_{4}$ & 23 & 48 & $\mathrm{u}_{4}$ & 23 & 95 \\
$\mathrm{D}_{5}$ & 14 & 30 & $\mathrm{U}_{5}$ & 14 & 93 & $\mathrm{~d}_{5}$ & 12 & 39 & $\mathrm{u}_{5}$ & 12 & 97 \\
$\mathrm{D}_{6}$ & 7 & 23 & $\mathrm{U}_{6}$ & 7 & 95 & $\mathrm{~d}_{6}$ & 6 & 26 & $\mathrm{u}_{6}$ & 6 & 101 \\
\hline
\end{tabular}

Common Median $\left(\mathrm{M}_{0}\right)_{\mathrm{n} 813}=77 \mathrm{yr}$ 
its inhabitants, the living cells or corals, have already gone. What is that built-in transforming power that terminates our body-state of $10^{12-10^{16}}$ united cells (22), and now replicated in some $7.10^{9}$ human beings living around the world today, remains to be elucidated. Our life span may be related to apoptosis (23), free radicals (24), telomere shortening (25), failure of stem cell regeneration (26), lack of caloric intake restriction (so that the body metabolism operates at an enhanced rate) (27), or something else. Apparently, these undetermined factors affect our lives more than we think. It is pertinent to note here that dietary restriction slows down cancer cell growth $(28,29)$, and today the "fat based ketogenic diet" (a highly restrictive calories, carbohydrate, and protein diet) (30) appears to be a promising new concept in cancer nutrition.

If we now look at odds for an insurance company to make (or lose) money on ensuring aged subjects, then the chance of a man's dying before the age of 65 and/or of 70 would be $\approx 35 \%$ and $\approx 40 \%$, and for women 60 and 65 years old $\approx 20 \%$ and $\approx 25 \%$, respectively. The first author's chance of making 72 would be about $55 \%$ and insurance company loss chance may be estimated at some $45 \%$, meaning that the odds for insurance company to make money were better. As a matter of fact, by knowing reasonably well the rate of death, the insurance companies could make more money; especially if they add some correction factor that would additionally improve their chances to earn somebodies money. Knowing the chance of accurately assessing life expectancy (the risk factor), may be also of some use to the practicing physician to set his diagnostic and therapeutic goals within a suitable agedependent time frame. Please, note, that we are not advocating the idea of penalizing aged people for being old and living too long by some insurance company actuarial accounts. Or any other gambling "Casino game" of the insurance companies. As a matter of fact, the provided statistical data may guide our Public Health authorities on how to provide a reliable and sustainable system of health protection to provide a decent end of life to its senior citizens beyond "the right to die“. Moreover, since senescence is a process with a different rates of change for the participating decaying individuals, there is a fallacy in reasoning that all the people lose their capacity, like working capacity, at the same chronological age. Indeed, there is no iron-clad „one size fits all“ age, that would force all women and men to retire at the age of 60 and 65 , respectively. Some of them would be already dead, but some of them would carry on in this "Casino game" of life.

The riddle of human life and death (31) will surely be an intriguing and challenging agenda for years to come (32). However, we have to develop new methods to accurately assess the actual status of the aging human body and to find the means on how to keep the frail body of old age as mobile and mentally alert as long as possible. Indeed, the senescent human being can be fragile, but still mobile and mentally alert. With the exploding ad- vancement of the medical science and technology (33), it may be difficult to provide all the needed health services for all the ailing and diseased aged people (34). Indeed, life span and senescence are a complex human biological traits not to be mechanically subsumed under the chronological age.

Acknowledgment. We thank prof. emeritus GI Lykken for his help with English language, and Ms. A Ranisate, Librarian, for her help with the literature references; both from the UND, Grand Forks, ND, USA.

\section{REFERENCES}

1. SCHRÖDINGER E 1964 My view of the world. Cambridge Univ Press, Cambridge.

2. LENNARTSSON C, AGAHI N, HOLS-SALEN L, KELFVE S, KAREHOLT I, LUNDBERG O, PARKER MC, THORSLUND M 2014 Data resource profile: The Sweedish Panel Study of Living Conditions of the Oldest Old (SWEOLD). Intl J Epidemiol 43:731738. https://doi.org/10.1093/ije/dyu057

3. HALTER J, OUSLANDER J 2009 Hazzard's geriatric medicine and gerontology, 6th ed. McGraw-Hill Professinal, New York, NY.

4. GRMEK MD 1964 Aging. In: Medicinska Enciklopedija. Jugoslavenski Leksikografski Zavod, Zagreb, Vol 9 (Shiz-Tul): p 308 316. [in Croatian]

5. RUSSINEK H, DE SANTI S, FRID D, TSUI VH, TARSHIS CY, CONVIT A, DE LEON MJ 2003 Regional brain atrophy rate predicts future cognitive decline: 6 year longitudinal MR imaging study of normal aging. Radiology 229:691-696. https://doi.org/10.1148/radiol.2293021299

6. FOPPIANI L, RUELLE A, BANDELLONI R, QUILICI P, DEL MONTE P 2008 Hypopituitarism in the elderly: Multifacted clinical and biochemical presentation. Curr Aging Sci 1:20-40. https://doi.org/10.2174/1874609810801010042

7. ROOK A, DAWBER R 1982 Diseases of the hair and scalp. Blackwell Sci Publ, Oxford.

8. MURPHY RA, IP EH, ZHANG Q, BOUDREAU RM, CAWTHON PM, NEWMANN AB, TYLAVSKY FA, VISSER M, GOODPASTER BH, HARRIS TB 2013 Transition of sarcopenia and determinants of transitions in older adults: A populationbased study. J Gerontol A Biol Sci Med Sci 69:751-758. https://doi.org/10.1093/gerona/glt131

9. SPIRA D, BUCHMANN N, NIKOLOV J, DEEMUTH I, STEINHAGEN-THIESSEN E, ECKARDT R, NORMAN K 2015 Association of low lean mass with frailty and physical perfroemance: A comparison between two operational definitions of sarcopenia - Data from the Berlin aging study II (BASE-II). J Gerontol A Biol Sci Med Sci. doi: 10.1093/gerona/glu246 [Epub ahead of print] https://doi.org/10.1093/gerona/glu246

10. RAJAOBELINA K, COUGNARD-GREGORIE A, DELCOURT C, GIN H, BARBERGER-GATEAU P, RIGALLEAU V 2015 Autoflorescence of skin advanced glycation and products: Marker of metabolic memory in elderly population. J Gerontol A Biol Sci Med Sci. doi: 10.1093/gerona/glu243 [Epub ahead of print] https://doi.org/10.1093/gerona/glu243

11. BURCHARDT P, DAWSON-HUGHES B, HEANEY RP (eds) 2004 Nutritional aspects of osteoporosis, 2nd ed. Elsevier Acad Press, Amsterdam.

12. LEE C-K, KLOPP RG, WEINDRFUCH R, PROLLA TA 1999 Gene expression profile of aging and its retardation by caloric restriction. Science 285:1390-1393.

https://doi.org/10.1126/science.285.5432.1390 
13. GATTS S 2008 A Tai Chi Chuan training model to improve balance ccontrol in older adults. Current Aging Sci 1:68-70. https://doi.org/10.2174/1874609810801010068

14. AKSENOV V, LONG J, LOKUGE S, FOSTER JA, LIU J, ROLLO CD 2010 Dietary amelioration of locomotor, neurotransmitter and mitochondrial aging. Exp Biol Med 235:66-76. https://doi.org/10.1258/ebm.2009.009219

15. BREEN L, PHILLIPS SM 2012 Interactions between exercise and nutrition to prevent muscle waste during aging. Br J Clin Pharmacol 75:708-715. https://doi.org/10.1111/j.1365-2125.2012.04456.x

16. AALEN OO, VALBERG M, GROTMOL T, TRETLI S 2014 Understanding variation in disease risk: the elusive concept of frailty. Int J Epidemiol. doi: 10.1093/ije//dyu 192 [Epub ahead of print]

17. BROWN M 1977 Charter of rights is adopted in UN. In: The New York Times: August 05, 2005 http://www.nytimes.com/learning/ general/onthisday/big/0618.html

18. NEILL A 1977 Life contingencies. Butterworth-Heinemann, London.

19. MOMČILOVIĆ B, PREJAC J, VIŠNJEVIĆ V, MIMICA N, MOROVIĆ S, ČELEBIĆ A, DRMIĆ S, SKALNY AV 2012 Environmental human silver exposure. Toxicol Environ Chem 94:12381246. https://doi.org/10.1080/02772248.2012.692556

20. MOMČILOVIĆ B, PREJAC J, VIŠNJEVIĆ V, SKALNAYA MG, MIMICA N, DRMIĆ S, SKALNY AV 2013 Hair iodine for human iodine status assessment. J Orthomol Med 28:1-11.

21. LEMONS DS 2002 An introduction to stochastic processes in physics. John Hopkins Univ Press, Baltimore, MD.

22. BIANCONI E, PIOVESAN A, FACCHIN F, BERAUDI A, CASADEI R, FRAQBETTI F, VITALE L, PALLERI MC, TASSANI S, PIVA F, PEREZ-AMONDIO S, STRIPPOLI P, CAHAIDER S 2013 An estimation of the number of cells in the human body. Ann Hum Biol 40:463-471. https://doi.org/10.3109/03014460.2013.807878

23. KUMAR S (ed) 1998 Apoptosis: Mechanisms and role in disease. Springer, Berlin. https://doi.org/10.1007/978-3-540-69185-3
24. SANZ A, STEFANATOS RKA 2008 The mitochondrial free radical theory of aging: A critical view. Curr Aging Sci 1:10-21. https://doi.org/10.2174/1874609810801010010

25. VON ZGLINICKI T, MARTIN-RUIZ CM 2005 Telomeres as biomarkers for aging and age-related diseases. Curr Mol Med 5:197203. https://doi.org/10.2174/1566524053586545

26. BICKFORD PC, TAN J, SHYTLE D, SANBERG CD, ELBADRI N, SANBERG PR 2006 Nutraceuticals sinergistically promote proliferation of human stem cells. Stem Cells Dev 15:118-123. https://doi.org/10.1089/scd.2006.15.118

27. HEILBRONN L, RAVUSSIN E 2003 Calorie restriction and aging: review of the literature and implications for studies in humans. Am J Clin Nutr 78:361-369. https://doi.org/10.1093/ajcn/78.3.361

28. KRITCHEVSKY D 2001 Caloric restriction and cancer. J Nutr Sci Vitaminol 47:13-19. https://doi.org/10.3177/jnsv.47.13

29. CAVALLINI G, DONATI A, GORI Z, BERGAMINI E 2008 Towards an understanding of the anti-aging mechanism of caloric restriction. Curr Aging Sci 1:4-9. https://doi.org/10.2174/1874609810801010004

30. SEYFRIED TN 2012 Cancer as a metabolic disease. On the origin, management, and prevention of cancer. Wiley, John Wiley \& Sons, Inc., Hoboken, NJ. https://doi.org/10.1002/9781118310311

31. MACIEIRA-COELHO A (ed) 1995 Molecular basis of aging. CRC Press, BocaRaton, Fl

32. BOVA B 1998 Immortality. Avon Books, New York, NY.

33. WEATHERALL D 2000 Foreword. In: Ledingam JGG, Warrell DA (eds) Concise Oxford Textook of Medicine. Oxford Univ Press, Oxford.

34. BAUZON S 2015 Classical distributive justice and the European Healthcare system: Rethinking the foundations of European Health Care in an age of crisis. JMed Philos. doi :10.1093/jmp/jhu078 [Epub ahead of print] https://doi.org/10.1093/jmp/jhu078

35. SHMULEVICH I, DOUGHERTY ER 2010 Probabilistic boolean network: The Modeling and Control of Gene Regulatory Networks. Society for Industrial and Applied Mathematics, Philadelphia, PA. https://doi.org/10.1137/1.9780898717631

Appendix 1. The median derivatives model (Population Size, PS = 1.000)

\begin{tabular}{|c|c|c|c|}
\hline \multicolumn{4}{|c|}{$\operatorname{Median}\left(\mathrm{M}_{0, \mathrm{n}=870}=0.499 \mu \mathrm{g} \cdot \mathrm{g}^{-1}\right)$} \\
\hline \multirow{3}{*}{\multicolumn{2}{|c|}{$\begin{array}{l}\text { Median Derivative Downward (Descending) } \\
\text { Branch }\left(\mathrm{D}_{0}{ }^{\prime} \mathrm{n}=435=\mathrm{PS} / 2=0.500\right) \\
\text { Descending Median Derivatives }\end{array}$}} & \multicolumn{2}{|c|}{ Median Derivative Upward (Ascending) } \\
\hline & & \multirow{2}{*}{\multicolumn{2}{|c|}{$\begin{array}{r}\text { Branch }\left(\mathrm{U}_{0, \mathrm{n}=435}=\mathrm{PS} / 2=0.500\right) \\
\text { Ascending Median Derivatives }\end{array}$}} \\
\hline & & & \\
\hline \multicolumn{2}{|c|}{$\mathrm{D}_{1}=\mathrm{D}_{0} / 2 \quad 0.250$} & \multirow{2}{*}{\multicolumn{2}{|c|}{$\begin{array}{r}\mathrm{U}_{1}=\mathrm{U}_{0}+\mathrm{U}_{0} / 2 \quad 0.750 \\
\mathrm{U}_{2}=\mathrm{U}_{1}+\mathrm{U}_{0} / 4 \quad 0.875\end{array}$}} \\
\hline \multirow{2}{*}{\multicolumn{2}{|c|}{$\mathrm{D}_{2}=\mathrm{D}_{0} / 4$}} & & \\
\hline & 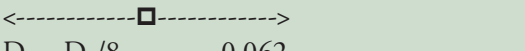 & <-------- & -------> \\
\hline \multicolumn{2}{|l|}{ <-----口---->> } & $\mathrm{U}_{3}=\mathrm{U}_{2}+\mathrm{U}_{0} / 8$ & (1)-----ロ----> \\
\hline $\begin{array}{l}\mathrm{D}_{4}=\mathrm{D}_{0} / 16 \\
<--\square-->\end{array}$ & 0.030 & $\mathrm{U}_{4}=\mathrm{U}_{3}+\mathrm{U}_{0} / 16$ & $\begin{array}{r}0.969 \\
<--\square-->\end{array}$ \\
\hline $\begin{array}{l}\mathrm{D}_{5}=\mathrm{D}_{0} / 32 \\
<\boldsymbol{\square}>\end{array}$ & 0.016 & $\mathrm{U}_{5}=\mathrm{U}_{4}+\mathrm{U}_{0} / 32$ & $\begin{array}{r}0.983 \\
<\square>\end{array}$ \\
\hline $\begin{array}{l}\mathrm{D}_{6}=\mathrm{D}_{0} / 64 \\
\square\end{array}$ & 0.008 & $\mathrm{U}_{6}=\mathrm{U}_{5}+\mathrm{U}_{0} / 64$ & $\begin{array}{r}0.992 \\
\square\end{array}$ \\
\hline
\end{tabular}

We studied the frequency distribution of hair iodine (H.I) median and its derivatives to assess the iodine deficiency, adequacy and excess. First we assess the median $\left(\mathrm{M}_{0}\right)$ hair iodine concentration of our subject population. By definition, one half of the studied population was above the median (upward median branch, $\mathrm{U}_{0}$ ), and the other half was below the median (downward median branch, $\mathrm{D}_{0}$ ). Hence, the population size (PS) for $\mathrm{M}_{0}$ is the sum of the respective upward and downward median branches around the central inflection "hinge" $\mathrm{M}_{0}$, i.e., $P S=\mathrm{U}_{0}+\mathrm{D}_{0}=0.5+0.5=1.0$. Both the respective upward and downward median branches can be further divided in the same "median of median" way into a series of sequential median derivatives $\left(\mathrm{U}_{0,1,2,3 \ldots \mathrm{n}-1, \mathrm{n}}\right.$ and $\left.\mathrm{D}_{0,1,2,3 \ldots \mathrm{n}-1, \mathrm{n}}\right)$. For every median derivative of the population, the actual hair iodine concentration can be identified. Thus, instead of mechanically throwing the preconceived percentile grid upon the observed data, we inferred the median derivative grid out from the data set itself (35). 